\title{
An Avicennian Engagement with and Appropriation of Mullā Ṣadrā Šīrāzì (d. 1045/1636)
}

The Case of Mahdī Narāqū (d. 1209/1795)

\author{
Sajjad H. Rizvi \\ University of Exeter, Exeter, $\mathrm{UK}$ \\ s.h.rizvi@exeter.ac.uk
}

\begin{abstract}
Recent scholarship on Avicenna and Avicennism has tended to focus on the spread and dissemination of his ideas in the early centuries. However, the later readings and contestations of Avicennism especially from the Safavid period onwards have been broadly neglected. In this paper on the most important philosopher of eighteenth-century Iran, Mahdī Narāqī, I provide a case study of the enduring significance of Avicennism, but one which has been transformed by Mullā Șadrā's critical reading of Avicenna. Narāqī demonstrates how Avicenna had been transformed and how the metaphysical debates between Avicennism and Mullā Ṣadrā had led to new synthetical positions.
\end{abstract}

\section{Keywords}

Avicennism - Mullā Șadrā - Narāqī - metaphysics - intellect - monism - incipience of the cosmos

A somewhat cursory intellectual history of Islamic philosophical traditions that focuses on the hegemonic authority of schools might yield the following threefold periodisation. The first would be an early 'golden age' beginning with the translation movement and the engagement with Neoplatonising Aristotelianism, critiquing but building upon the tradition of the commentators on Aristotle and on Plotinus, culminating in Avicenna. ${ }^{1}$ This would be fol-

1 Ulrich Rudolph et al (eds.), Philosophy in the Islamic World, Vol. 1 8th-10th Centuries, (Leiden: Brill, 2016). 
lowed by an age of the 'pandémie avicennienne,' both the perpetuation and development of the Avicennian tradition starting with the first generation of his student Bahmanyār (d. 458/1067) and consolidating with the appropriation of Avicennism by the kalām tradition and the articulation of the thought of Nașîr al-Dīn al-Ṭūī (d. 672/1274), as well as the critiques of Avicenna by Shahrastānī (d. 528/1153), from an Ismaili apophatic perspective, Suhrawardī (d. 587/1191) from a more Platonic perspective, and Averroes (d. 595/1198) from a more 'orthodox' Aristotelianism. ${ }^{2}$ The final stage (before the modern eclipse of 'traditional' philosophy in the Islamic world) would thus be the replacement of Avicenna with Mullā Ṣadrā Šĩāzì (d. 1045/1636) as the dominant philosopher of the Islamic traditions from the Safavid period, spreading even to the Ottoman and Indian contexts. ${ }^{3}$ Of course, it is entirely possible for each period to have differing and rival conceptions of philosophy debating among themselves. My concern in this paper is to nuance this third period and consider the perpetuation and transformation of the differing modes of Avicennism. The contention is that Mahdī Narāqī's espousal of Avicenna and critical engagement with Mullā Ṣadrā signalled less a doctrinaire espousal of Avicennism and more a promotion of a highly transformed Avicennism that was already influenced by a Sadrian reading of the work of the master.

Considered from the perspective of contemporary Islamic philosophy in Iran, it seems that the thought of Mullā Șadrā Šìnāzī (d. 1045/1636) is dominant. The plethora of comparative studies in which Mullā Șadrā represents Islamic philosophy as a dominant, triumphal figure, with any number of modern European thinkers seems to suggest as much. ${ }^{4}$ Mullā Șadrā is championed as the Kant of Iran, and like Thomas Aquinas in the Catholic tradition is analyticised, made more continental, is exegetically glossed, and is read for different purposes in identity politics. ${ }^{5}$ Similarly, an examination of philosophical tradi-

2 Jean R. Michot, "La pandémie avicennienne au Vie/Xııe siècle," Arabica, 10.3 (1993): 287344; Ahmed al-Rahim, The Creation of Philosophical Tradition: Biography and the Reception of Avicenna's Philosophy from the Eleventh to the Fourteenth Century AD (Wiesbaden: Otto Harrassowitz, 2018).

3 Henry Corbin, La philosophie iranienne islamique aux XVIIe et XVIIIe siècles (Paris: Buchet Chastel, 1981); Christian Jambet, Qu'est-ce que la philosophie islamique? (Paris: Gallimard, 2011); Seyyed Hossein Nasr and Mehdi Aminrazavi (eds.), An Anthology of Philosophy in Persia, Vol. 5: From the School of Shiraz to the Twentieth Century (London: Tauris, 2015), esp. 119-528.

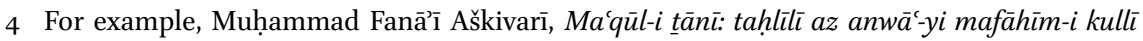
dar falsafa-yi islāmī va garbī (Qum: Intišāāāt-i mu’assasa-yi āmūzīš va pažhūhišīyi Imām Humaynī, 1387 Š/2008); Alparslan Açikgenç, Being and Existence in Sadra and Heidegger: A Comparative Ontology (Kuala Lumpur: ISTAC, 1993).

5 Sajjad H. Rizvi, Mullā Șadrā and Metaphysics: Modulation of Being (London: Routledge, 2009), 4-14. On the reception of Kant, see Roman Seidel, Kant in Teheran: Anfänge, Ansätze und Kon- 
tions in the Qajar period demonstrates the first stage of his dominance when it was the study of his texts that displaced Avicenna from the core of the curriculum. ${ }^{6}$ However, it took some time for the hegemony of the Šìrāzì thinker to become established and his work and key ideas were contested from a number of perspectives; for example, his views on the possibility, indeed the necessity for motion (and quantity and quality) to pertain to the category of substance (haraka ğawharīya, against Avicenna) which was an important corollary of his theory of the ontological priority of existence (așālat al-wuğùd) and its modulation (taškīk), were widely disputed. ${ }^{7}$ In this paper, I will examine an important episode of Avicennian engagement with the thought of Mullā Șadrā, as expressed in the work of the eighteenth-century thinker Mahdī b. Abī Dharr Narāqī (d. 1209/1795) as an Avicennian philosopher inspired by Mullā Șadrā’s reading of Avicenna but also critical of his more mystical intuitions about ontology. But first let us begin with the consideration of the Avicennian tradition in the Safavid period and the earliest such responses to Mullā Șadrā to make sense of the Avicennisms that Narāqī inherited.

These disputations began in the immediate generation of Mullā Șadrā's students including 'Abd al-Razzāq Lāhīğì (d. 1072/1661) who, on the basis of a defence of Avicennism, rejected the two key elements of Șadrian ontology in his work. ${ }^{8}$ But in particular, it was the 'school' of Rağab 'Alī Tabrīzī (d. 108o/

texte der Kantrezeption in Iran (Berlin:Walter de Gruyter, 2014). There are plenty of works that pit Mullā Ṣadrā against Kant. See the works of Murtażā Muṭahharī, such as his four volume commentary on the text of Mullā Hādī Sabzavārī (d. 1298/1873), Šarh-i mabsūt-i manzūma (Tehran: Intišāāāt-i Ḥikmat, ${ }_{1363}$ Š/1985), and his notes on the lectures of 'Allāma Ṭabāṭabā'ì published in five volumes as Ușūl-i falsafa va-raviš-i riālizm (Qum: Intišārāt-i Șadrā, 1382 Š/2003). Muțahharī and Țabāțabāì are known for their deployment of Mullā Ṣadrā against modern European philosophy—see Urs Gösken, Kritik der westlichen Philosophie in Iran. Zum geistesgeschichtlichen Selbstverständnis von Muḥammad Ḥusayn Ṭabāțabā̄ìund Murtażā Muțahharī (Munich: Walter de Gruyter, 2014).

6 Sajjad H. Rizvi, "Hikma mutacaliya in Qajar Iran: Locating the Work of Mulla Hadi Sabzawari," Iranian Studies, 44.4 (2011): 473-96; and idem, "Alī Nūrī," in Philosophy in Qajar Iran, ed. by Reza Pourjavady (Leiden: Brill, 2018), 125-78, as well as the other contributions in the same volume.

7 'Alī-Riżā Znakāvatī Qarāgiuzlū, "Sayrī dar naqd-i afkār-i Mullā Ṣadrā dar čahār qarn-i ahīr," Āyina-yi pažūhiš 10.57 (1378 Š/1999): 14-21.

8 'Abd al-Razzāq Lāhīōī, Gawhar-imurād, ed. by Zayn al-'Ābidīn Qurbānī Lāhīğīi (Tehran:Daftari tablìgāt-i islāmī, 1388 Š/20o9), 192-6; idem, Šawāriq al-ilhām fi šarḥ Tağrìd al-kalām, ed. by 
1669) which rejected the Șadrian theory of existence often on the grounds that there could be no analogy between Creator and created-they preferred a more apophatic approach to philosophy as one can see in Tabrīzì's two main texts on the nature of God, Proof of the Necessary (It bāt-ivāăib) and the Fundamental Principle (Așl al-așill). ${ }^{9}$ In the latter text, Tabrīzì posits four objections. First, he rejected the analogy between the term 'existence' posited for the contingent and for the necessary based on the Arabic Neoplatonic axiom ex uno non fit nisi unum. ${ }^{10}$ Second, he critiqued the ontological priority of existence by arguing that quiddities are instantiated without existence, and hence they are 'made' (mağ ūla) by God directly without any need for existence." This broadly follows the position of Ğalāl al-Dīn Dawānī (d. 908/1502) on mağ ūlēyat al-māhìya, although Tabrīzì does not invoke his authority. ${ }^{12}$ Third, he rejected

Akbar Asad 'Alī-zāda (Qum: Mu’assasa-yi Imām Ṣādiq, 1391 Š/2012), I, 143-6o, 221-4, III, 171-180; idem, al-Kalima al-țayyiba, ed. by Ḥamīd 'Ațāī Nazarāi (Tehran: Mu’assasa-yi pažūhišī-yi hịikmat va falsafa-yi İrān, 1391 Š/2012), 130-2, 133-6; Corbin, La philosophie iranienne islamique, 103-9.

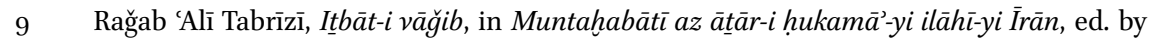
Sayyid Ǧalāl al-Dīn Āštiyānī (Qum: Daftar-i tablìgāt-i islāmī, 1378 Š/1999), I, 239-58; Rağab 'Alī Tabrīzī, Aṣl al-aṣil, ed. by 'Azīz Ğavānpūr Hiravī and Ḥasan Akbar Bayraq (Tehran: Anğuman-i mafāhnir va ātāar-i farhangī, 1386 Š/2007); Nasr and Aminrazavi (eds.), An Anthology of Philosophy in Persia, 285-304; Corbin, La philosophie iranienne islamique, 8395 .

10 Tabrīzì, Aṣl al-așil, 26-9. The axiom is best known through Avicenna, The Metaphysics of the Healing, ed. and tr. by Michael Marmura (Provo, ut: Brigham Young University Press, 2005), book IX, chapter 4, 328; and al-Išārāt wa-l-tanbīhāt ma šarhay, ed. by Maḥmūd Šihābī (Qum: Našr al-balāgàa, 1375 ک̌/1996), III, 122; and his student Bahmanyār, Kitāb altaḥṣill, ed. by Murtaḍā Muțahharī (Tehran: Tehran University Press, 1375 Š/1996), 531-2. Cristina d'Ancona has suggested that the roots of the axiom lie in the Arabic Plotinus and Proclus-see "Ex uno non fit nisi unum Storia e preistoria della dottrina avicenniana della prima intelligenzia," in Per una storia del concetto di mente, ed. by Eugenio Canone (Firenze: L.S. Oschki, 2007), 29-55. There are other earlier echoes, for example in the possibly apocryphal Fārābian commentary on the 'so-called treatise of Zeno:' Šarh risālat Zīnūn, ed. by Ḥāmid Nāği Iṣfahānī, in Ganğina-yi Bahāristān Hikmat II, ed. by 'Alī Awğabī (Tehran: Kitābhāna, mūza va markaz-i asnād-i Mağlis-i Šūrā-yi Islāmī, 1387 Š/20o8), 128. For a study that questions the attribution of this text to Fārābī, see Josep Puig, "Un tratado de Zenón el Mayor. Un comentaria atribuido a al-Farabi," La Ciudad de Dios 201 (1988): 287-321.

11 Tabrīzī, Aṣl al-aṣill, 55-6o, 68-9.

12 Reza Pourjavady, "Jalāl al-Dīn al-Dawānī (d. 908/1502), Glosses on 'Alā’ al-Dīn al-Qūshjī's Commentary on Nașīr al-Dīn al-Ṭūsī's Tajrīd al-ítiqūd," The Oxford Handbook of Islamic Philosophy, ed. by Khaled el-Rouayheb and Sabine Schmidtke (New York: Oxford University Press, 2017), 415-37, esp. 422-3, 428-9; Gulām-Ḥusayn Ibrāhīmī Dīnānī, Ğalāl alDīn Davānī: filsūf-i dawq al-ta’alluh (Tehran: Intišārāt-i Hirmis, 1395 Š/2016), 18-20, 599o. 
the Sadrian position of motion in the category of substance. Fourth, he denied a mental mode of existence (wuğ $\bar{u} d \underline{d}$ dihnī ) — an issue that was broadly accepted in the Avicennian tradition stemming from Nașīr al-Dīn al-Ṭūì (d. 672/1274). ${ }^{13}$ However, he did accept the Sadrian position on the infallibility of knowledge by presence. ${ }^{14}$ Dawānīs positions were broadly eclipsed from the Iranian milieu in this period, which may account for why the tendency associated with Tabrīzì did not survive. ${ }^{15}$ In this sense, the Essence of Philosophy ('Ayn al-hikma) of Mīr Qawām al-Dīn al-Rāzī al-Ṭihrānì (d. 1093/1683), despite being more philosophically sophisticated and Avicennian than that of his teacher Tabrīzī, was the last gasp of the school that rejected Sadrian innovations in metaphysics and insisted upon the radical ontological and semantic distinction between God and the cosmos. ${ }^{16}$ The exception were the Huānsārīs in the seventeenth century whose positions on existence were reminiscent of Dawānī. It was thus left to the mainstream Avicennian tradition to adapt to Sadrian positions and to retain a critical attitude.

Therefore, most of the critiques of the metaphysics of Mullā Șadrā came from the mainstream Avicennian tradition in their commentary cultures on

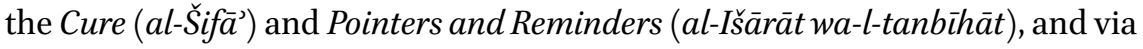
the commentary tradition on the pithy kalām text Sublimation of Belief (Tağrìd al-ítiqua $d$ ) of Nașīr al-Dīn al-Ṭusīi, and its two commentaries, the 'old' by Šams al-Dīn al-Ișfahānī (d. 749/1348) and the 'new' by 'Alī al-Qūššì (d. 879/1474). That 'orthodox Avicennian' tradition was unhappy with the Sadrian shift towards a more thoroughly neoplatonising and mysticising approach to philosophy, moves which were arguably part of the Safavid mainstream through its embrace of the pseudo-Aristotelian Theologia Aristotelis and works attributed to al-Fārābī (d. 339/951) associated with the dossier of Plotinus, Proclus and others in Arabic Neoplatonism. ${ }^{17}$ The Safavid period was one attuned to the conscious revival of classical heritages, Hellenic and ${ }^{\mathrm{S}} \overline{\mathrm{i}} \overline{\mathrm{i}}$, the former because all

\footnotetext{
13 Tabrīzì, Aṣl al-aṣil, 6o-6.

14 Tabrī̄ī, Aṣl al-așill, 86-9.

15 Pourjavady, "Jalāl al-Dīn al-Dawānī (d. 908/1502)," 433-5; contra Robert Wisnovsky, "Avicenna's Islamic reception," in Interpreting Avicenna, ed. by Peter Adamson (Cambridge: Cambridge University Press, 2013), 190-213, esp. 209.

16 Mīr Qawām al-Dīn al-Ṭihrānī Rāzī, 'Ayn al-ḥikma wa-ta lìqāt, ed. by 'Alī Awğabī (Tehran: Intišārāt-i kitābhāna, mūza va markaz-i asnād-i Mağlis-i Šūrā-yi Islāmī, 1378 Š/1999); Corbin, La philosophie iranienne islamique, 206-18. His contemporary did much the samesee 'Alī-qulī b. Qarağgàày Hुān, I hyyả'-yi hịmat, ed. by Fāțima Fanā, 2 vols. (Tehran: Mīrāt-i maktūb, $1377 \check{S} / 1998$ ).

17 Reza Pourjavady and Sabine Schmidtke, "An Eastern Renaissance? Greek Philosophy under the Safavids," Intellectual History of the Islamicate World, 3 (2015): 248-9o.
} 
philosophy was ultimately a prophetic revelation and inheritance and the latter because it was the direct legacy of prophecy.

Thus far, as El-Rouayheb observed, we have tended to ignore the critics of Mullā Șadrā, especially from the Avicennian tradition, in the intellectual history of the early modern Islamicate East. ${ }^{18}$ Therefore, we need to re-examine that tradition especially in light of the challenge of Mullā Șadrā. He fundamentally undermined Avicenna and Avicennism in a number of ways: he displaced Avicennian substance metaphysics and its hylemorphism with a more process oriented metaphysics of existence in which category theory became redundant; he shifted epistemology away from the binarism of what the external and internal senses perceive and the distinction within intellection between abstraction from sense data and reception of the universals from the transcendental active intellect towards a more monistic reading of knowledge as states of existence and faculties of the soul; and he set aside the Avicennian compromise on the spiritual resurrection of the person sitting alongside the scriptural account of corporeal resurrection with his own hybrid theory of the body of the afterlife being 'created' by the human soul as instrument of the divine. His ideas and method were radically different, even when located in Avicennian paradigms and questions.

As Wisnovsky has shown, Mullā Șadrā inherited a reading of Avicenna's Metaphysics of al-Šifäa and al-Išărāt wa-l-tanbīhāt that was mediated in the first case by the Šīi ì tradition of 'Allāma Ibn al-Muțahhar al-Hiillì (d. 725/1325) and the Safavid thinkers and in the latter case by the dual heritage of Nașīr al-Dīn al-Ṭusī and his influential commentary Resolving the Difficulties in the Pointers (Hall muškilāt al-išārāt) and Faḩr al-Dīn al-Rāzì (d. 6o6/1210) and his more critical adoption of Avicenna in his own commentary on Pointers and his other works. ${ }^{19}$ In fact, it was the impact of the latter upon the kaläm traditions, both Sunnī and $\check{S} \bar{i} i_{1}$ that defined Avicennism in the early modern period. ${ }^{20}$ For the

18 Khaled El-Rouayheb, Islamic Intellectual History in the Seventeenth Century: Scholarly Currents in the Ottoman Empire and the Maghreb (Cambridge: Cambridge University Press, 2015), 361 .

19 Robert Wisnovsky, "Avicennism and Early Exegetical Practice in the Commentaries on the Ishärāt," Oriens 41 (2013): 349-78; idem, "Avicenna's Islamic reception;" Jon McGinnis, "Nașīr al-Dīn al-Ṭūsī (d. 1274) Sharh al-ishārāt," in The Oxford Handbook of Islamic Philosophy, ed. by el-Rouayheb and Schmidtke, 326-47; Ayman Shihadeh, "Al-Rāzìs (d. 1210) Commentary on Avicenna's Pointers," in The Oxford Handbook of Islamic Philosophy, ed. by el-Rouayheb and Schmidtke, $296-325$.

20 Robert Wisnovsky, "One Aspect of the Avicennian Turn in Sunnī Theology," Arabic Sciences and Philosophy 14 (2004): 65-100; Heidrun Eichner, The Post-Avicennian Philosophical Tradition and Islamic Orthodoxy: Philosophical and Theological Summae in Context, Habilita- 
later tradition in the East, al-Ṭusīi is a pivotal figure since it was his twin contribution to the reading of Avicenna's metaphysics - the postulation of a mode of existence called the mental ( $\left.\operatorname{dihni}^{\prime}\right)$ and that existence is said of in many ways in a graded or modulated manner (taškīk al-wuğūd) — that was taken up in the language of ontology. ${ }^{21}$ However, it was Mullā Șadrā who transferred these key notions into commitments to a particular vision of reality- the modulated singularity of existence (haqiqqa wăhida mušakkaka) was not just about the semantics of the term 'existence' but constituted a description of an actual metaphysics. ${ }^{22}$ The Pointers tradition was then filtered down through the 'adjudication' (muḥākama) of al-Ṭūsìss student Quṭb al-Dīn Taḥtānī (d. 766/1365), favouring his teacher, followed by the influential glosses of Mìrzāăān Bāginawī (d. 994/1585). The other important strand of the Avicennian tradition came through the Tağrìd of al-Ṭūī and the Glosses of al-Šarīf 'Alī Ğurğānī (d. 816/1414) on the 'old' commentary of Šams al-Dīn al-Iṣfahānī, the two Glosses of Șadr alDīn Daštakī (d. 9o3/1497) and the three of Ğalāl al-Dīn Dawānī (d. 9o8/1502) in response on the 'new' commentary by Qūššìi, and then the Glosses of Šams al-Dīn Hafrì (d. 957/1550) on the proof for the existence of God section (almaqșad al-tâlit fí ițbāt al-șānic) of the 'new' commentary. ${ }^{23}$ Hafrī was an influential confluence of the two strands because he also wrote a set of glosses on Taḥtāni’s adjudication on Pointers. ${ }^{24}$ These internal debates in Šĩrāz were particularly vehement on the first section of the Tağrìd on the ontology (especially whether God could be characterised by 'absolute existence' or wuğüd muțlaq) and on the third section on the divine attributes. We see glimpses of the Daštakī-Dawānī debates in the work of Mullā Ṣadrā himself, but certainly in the many subsequent marginalia of the later Safavid period on two Glosses: Glosses on Dawānì's 'older' Gloss (hā̌siya qadīma) starting with the generation of the students of Dawānī all the way through to the post-Safavid period, broadly

tionsschrift, Halle, 20o9; eadem, "Handbooks in the Tradition of Later Eastern Ash'arism," in The Oxford Handbook of Islamic Theology, ed. by Sabine Schmidtke (Oxford: Oxford University Press, 2016), 494-514.

21 Ṭūsì did not invent these concepts in the Avicennian tradition; however, he emphasised their centrality to reading Avicennian metaphysics—see Avicenna, al-Ǐšărātwa-l-tanbīhāt ma šarhay, III, 6-7, 17-8.

22 Wahid Amin, Nașir al-Dìn Ṭüsī and the Avicennan Tradition: Metaphysics and Mental Existence, D.Phil. dissertation, Oxford, 2016.

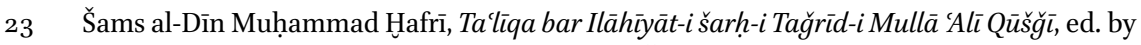
Firūza Sā'atčìyān (Tehran: Mīrāt-i maktūb, 1382 Š/2003).

24 Šams al-Dīn Muḥammad Ḩafrī, Ḥāšiya al-muhākama bayn šarḥay al-išāāāt, ed. by 'Abd Allāh Nūrānī in Ganğinna-yi Bahāristān: Hikmat I, ed. by 'Alī Awğabī (Tehran: Intišārāt-i kitābhāna, mūza va markaz-i asnād-i Mağlis-i Šūrā-yi Islāmī, 1379 Š/20oo), 137-99. 
divided into those who defended Dawānīs positions (earlier and then moving beyond Iran) and those who criticised or went further (especially later and among those who remained in Iran), and Glosses on Hafrī throughout the seventeenth century between students of Mīr Dāmād and Mullā Ṣadrā, including those who perpetuated the Dawānī-Daštakī debates. Often commentaries and independent treatises on the same topic cluster around one another as texts are creatures of conversations. Before one can have a fuller intellectual history of the reception of Avicennism through kaläm commentaries, one would have to study these texts that on the whole are extant in multiple copies.

The Avicennian tradition in the Safavid period could not ignore the impact of Mullā Șadrä's glosses on al-Šif $\tilde{a}$. Most of the Avicennian works in the period before were focused on the commentary cycles of al-Išärāt and the Tağrìd. The revived interest in the Metaphysics of al-Šifä of Avicenna began in Šīāz with Cure for the Hearts (Šifă’ al-qulüb) of Ġiyāt al-Dīn Daštakī (d. 949/1542), who devoted most of his glosses to the definition of philosophy and ontology of book 1 (he wrote a larger set of glosses entitled Gardens of pleasure [Riyā al al-ridwān] prior to Šifä but it does not seem to be extant),, ${ }^{25}$ and ran on through the glosses of Mīrzāğān Bāgnnawī Šìrāzī, a student of the philosophers of Shiraz, Mīr Dāmād (d. 1040/1631), and his student Sayyid Aḥmad 'Alawī (d. c. 106o/165o); in fact it would not be an exaggeration to say that Mīr Dāmād and his students, taking on the mantle of the Daštakiss, defined the Avicennian tradition for the period. ${ }^{26}$ The popularity of both the Metaphysics of al-Šif $\bar{a}^{2}$ and al-Ǐs̄ärät is well attested in the sources that mention many teachers of these texts and marginalia and commentaries. There were even translations into Persian of these texts by Sayyid 'Alī b. Muhammad al-'Urayḍī al-Imāmī (d. 1120/1708) who had studied with Ḥusayn Huwānsārī. ${ }^{27}$

25 Ġiyāt al-Dīn Manșūr Daštakī, Mușannafāt, ed. by 'Abdullāh Nūrānī (Tehran: Anğuman-i mafāhiir va ātāār-i farhangī, 1386 Š/2007), II, 377; idem, Šifä’ al-qulūb wa-tağawhar al-ağsām, ed. by 'Alī Awğabī (Tehran: Intišārāt-i kitābhuāna, mūza va markaz-i asnād-i Mağlis-i Šūrā-

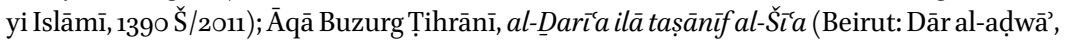
1983), XI, 325 .

26 Daštakī, Muṣannafāt, II, 377-49o; Ibn Sīnā, al-Šifā' (al-ilāhīyāt): ma` ta'īqāt Șadr al-mu-

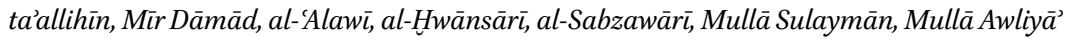
wa-ġayrihim, ed. by Ḥāmid Nāğĩ Ișfahānī (Tehran: Anğuman-i mafāhiir va ātārr-i farhangī, ${ }_{1383}$ Š/2004); Ahab Bdaiwi, Shici Defenders of Avicenna: An Intellectual History of the Dashtakī Philosophers of Shiraz, Ph.D. dissertation, Exeter, 2014; Robert Wisnovsky, "Avicennism and Early Exegetical Practice." This is not to deny the influence of Dawānī on Mīr Dāmād, but rather to indicate that the Daštakīs ushered in a 'Šici Avicennism' whose leadership Mīr Dāmād adopted.

27 Sayyid Aḥmad al-Ḥusaynī, Talāmidat al-'Allāma al-Mağlisī wa-l-muğāzūn minhu (Qum: Kitābhāāna-yi Āyatullāh Mar'ašī Nağafĩ, 1410/1989), 44; Muḥammad Riżā Zādhūšs, Dīdār bā 
However, the glosses of Mullā Ṣadrā were well known, extensive, widely attested and posed a challenge. ${ }^{28}$ Extant in the manuscript libraries of Iran, there are a number of codices from the seventeenth century including an acephalous holograph (MS Mar'ašī Qumm 914). ${ }^{29}$ His commentary runs to the end of chapter 5 of book 6 of the Metaphysics on causality and providence, hence missing out the following books on the proof for the existence of God as the necessary existence, on governance and on eschatology. He also consistently continues the commentary tradition in the East of al-Ǐ̌ārāt by defending al-Ṭūsì's reading and criticizing al-Rāzì's objections. By contrast, the Key to the Cure (Miftāh alšifă') of 'Alawī, an extensive commentary by the son-in-law of Mīr Dāmād, has seven extant codices from the 17 th century including the holograph (MS Mağlisi šūra-yi Islāmī Tehran 1789) but is barely cited in the commentary tradition of subsequent generations. ${ }^{30}$ This could also be because he defends Avicennian positions attacked and rendered irrelevant (insofar as they were little discussed afterwards since the debate had moved on) by Mullā Ṣadrā such as his defence of Avicennian eschatology from book 10, a minimalist reading of divine simplicity in chapter 4 of book 8, and his defence of Avicenna's theory of God's knowledge of particulars in chapter 6 of book 8, which Mullā Șadrā sets aside for his use of the identity theory of knowledge (within a discussion on knowledge by presence- ilm hudūuri $).{ }^{31}$ Since he was writing around the same time as Mullā Șadrā, it is also quite likely that he was not aware of his reading or did not consider it significant enough to engage.

An example of the influence of Mullā Șadrā's glosses can be seen soon after his death in the glosses on the Metaphysics of al-Šifă’ by Muhammad Bāqir Sabzawārī (d. 109o/1679), a leading court theologian and himself a student of Ḥusayn Ḩwānsārī, Mīr Abū-l-Qāsim Findiriskī (d. 1050/1641), and of other students of Mīr Dāmād, as well as being a leading court jurist under 'Abbās II. ${ }^{32}$

filsūuān-i Sipāhān (Tehran: Mu’assasa-yi pažūhišǐ-yi hịikmat u falsafa-yi Īrān, 1391 Š/2012), 161; Ivana Panzeca, "On the Persian translations of Avicenna's Ilāhiyyāt," Documenti e studi sulla tradizione filosofica medievale 28 (2017): 553-67.

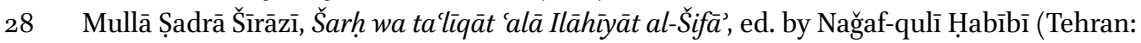
Intišārāt-i Bunyād-i ḥikmat-i islāmī-yi Ṣadrā, 1382 Š/2003).

29 Mușțafā Dirāyatī (ed.), Fihristvāra-yi dast-nivišt-hā-yi İrān [Dinā] (Qum: Al-Hādī, 1389 Š/2010), IV, 308-9.

30 Dirāyatī, Fihristvāra, IX, 1037-8.

31 Sayyid Ahmad al-'Alawī, Miftāḥ al-Šifā̄, in Muntahabātī, ed. by Āštiyānī, II, 39-54, 739o, 115-43; Mullā Ṣadrā Šīrāzī, al-Hikma al-mutáāliya fí-l-asfār al-'aqlīya al-arba'a, ed. by Sayyid Muḥammad Ḩāminihī et al. (Tehran: Intišāāāt-i Bunyād-i ḥikmat-i islāmī-yi Ṣadrā, 1383 Š/2004), IX, 199-223, VI, 91-97, VI, 184-217, 251-67, III, 339-47, 481-529.

32 al-Ḥurr al-'Āmilī, Amal al-āmil fí 'ulamā' Ğabal 'Āmil, ed. by Sayyid Ahmad al-Ḥusaynī alAškiwarī (Nağaf: al-Maṭba'a al-Ḥaydariyya, 1966), I, 250-2. 
Eight manuscripts are extant of his commentary that runs to book 8 of the Metaphysics. Sabzawārī consistently cited Mullā Șadrā as 'one of the scholars' (ba'd al-fudalä) or 'chief of the great scholars' (Șadr al-afädil). At the same time, he criticised his brother-in-law and teacher (or at the very least fellow student of Findiriskī) Hwwānsārī on a number of points and supported the positions of Mullā Ṣadrā. On some points he tried to adjudicate between the two; for example, on whether existence that is the subject of metaphysics is an abstract concept ('absolute existence' or 'being qua being'), or whether it primarily refers to substance ( ğawhar) or whether to God as the ultimate referent for existence, Sabzawārī suggested that the difference between the two was really a semantic squabble (munāqiša lafžìya). ${ }^{33}$ Sabzawārī approvingly quoted Mullā Ṣadrā arguing that metaphysics does not just study substances but being qua being and secondarily provides the subjects of all the other sciences, a position that is critiqued by Huwānsārī to whom Sabzawārī responds. ${ }^{34}$ Most importantly, Sabzawārī considers Hwwānsārīs objections to be misplaced because they seek to defend Avicenna by sticking faithfully to the text as an exegetical exercise. According to him, Hwānsārī fails to appreciate that Mullā Șadrā's glosses are concerned with the philosophical meaning and explanation of the issues that Avicenna discusses and not of Avicenna himself (lä tafsìr șarị̣ al-lafž). ${ }^{35}$ Sabzawārī did not study directly with Mullā Șadrā or even with any of his students as far as we know; however, it is clear through his copious citations of the Šìnāzì thinker that he considered him to have fundamentally altered the Avicennian tradition - away from the legacy of Mīr Dāmād—and to have presented a novel and critical way of reading Avicenna. It was this new reading to which Huwānsārī and others objected.

It might be useful to catalogue the challenge that Mullā Șadrā's reading posed by considering some of the key issues of dispute with Avicenna in his major works, the Transcendent Philosophy of the Four Journeys of the Intellect (al-Hikma al-muta'äliya fi-l-asfär al-'aqlīya al-arba'a) completed in 1037/1628, and his Gloss on the Metaphysics of al-Šifä' completed some time between 1041/1631 and 1044/1634, in which he often refers back to the former work. As such, they are works that represent his mature thought, and it is possible that the incompleteness of his glosses may be due to the fact that he died in $1045 / 1636$.

33 Mullā Ṣadrā, Šarḥ, I, 23-4; Sabzawārī, Ḥāšìya, in Muntahabātī, ed. by Āštiyānī, II, 550-1; Huwānsārī, Hēǎšiya, in Muntahabātī, ed. by Āštiyānī, I, 377 .

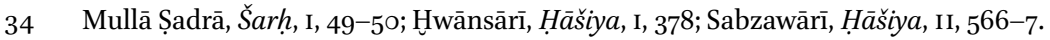

35 Sabzawārī, Hāǎšiya, II, 574-5 and 581-2, citing Mullā Ṣadrā, Šarh, I, 5o. 
There are three broad areas in which his position was at odds with Avicenna. The first concerns the nature of the structure of existence and its modulation. Whilst allowing for modulation of the concept of existence, Avicenna denies that modulation pertains to the reality of existence or even is an essential feature of existence. ${ }^{36} \mathrm{Al}$-Ṭusì goes further by allowing for that semantic modulation to cover the intensification and debilitation of existence, and Mullā Șadrā cites these three ways in which modulation occurs: by precedence, by priority, and by intensity (al-awlawìya, al-aqdamīya, al-ašaddīya ). ${ }^{37}$ Mullā Șadrā therefore critiqued Avicenna for failing to see through the logic of the semantics of modulation. In his critique of the Avicennian position, he once again stipulates that "existence is a simple reality and nature that differs in varying degrees of perfection and imperfection and intensity and debility and priority and posteriority, all of which pertain to its very essence. [...] It is the principle of realities and their essence. [...] If you have realised this, and your heart has opened to it and you have practised your reason on this, then many further subjects of knowledge will be disclosed to your heart." ${ }^{38}$ Therefore, realising the modulated nature of existence opens the ways for resolving many other philosophical aporiai.

Second, he took Avicenna (and his followers) to task for failing to understand the nature of the soul and its rational faculty, and in particular for understanding that intellection involves a process of union between the intellecting substance and what is intellected. ${ }^{39}$ He cites the important passages in Pointers and in the De Anima ( $f \grave{\iota} l-n a f s$ ) of al-Šif $\bar{a}^{\prime}$ on the denial of the identity thesis. ${ }^{40}$ Avicenna's confusion arises from a mistaken conception of the union of the two as well as espistemological infallibilism. As elsewhere, Mullā Șadrā's inspiration comes from the Neoplatonic Theology of Aristotle. ${ }^{41}$

Third, his position on the essential nature of motion as a feature of existence was contrary to Avicenna. The controversy of motion in substance was recognised early on along with a classic Avicennian criticism that the accidental motion of bodies in this sublunary sphere is an effect of the eternal

36 Ibn Sīnā, al-Šifẳ : ilāhīyāt, ed. by Ğ. Anawātī, Saīì Zāyid, Ibrāhīm Madkūr et al. (Cairo: alHay’a al-mișrīya al-āmma li-l-kitāb, 196o), I, 34; Mullā Șadrā, Šarh, I, 129-31.

37 Ibn Sīnā, al-Išārāt wa-l-tanbīhāt ma šarḥay, III, 32-4; Mullā Șadrā, Šarh, I, 129.

38 Mullā Ṣadrā, Šarḥ, I, 499-5oo.

39 Mullā Ṣadrā, Asfār, III, 339.

40 Mullā Ṣadrā, Asfār, III, 347-51, citing Ibn Sīnā, al-Išārāt, III, 292-296, and Ibn Sīnā, al-Šifä̃: fì l-nafs, eds. Ğ. Anawātī, Saīi Zāyid, Ibrāhīm Madkūr et al. (Cairo: al-Hay’a al-miṣrīya al'āmma li-l-kitāb, 196o), 212-3.

41 Mullā Șadrā, Asfār, III, 343, citing (ps.-)Aristotle, Uteülūğiyā, in Aflūṭinn 'ind al-'arab, ed. by 'Abd al-Raḥmān al-Badawī (Cairo: L' Institut français, 1947), mìmar vıII, 117. 
motion of the celestial spheres. This is pre-empted along with the affirmation that motion in the category of substance is an essential feature of the renewal of natural bodies insofar as they are existent. The very definition of substance goes beyond Avicenna; substances are not just primary referents of existence that exist by virtue of themselves and do not exist in any other substrate, but rather are units of becoming in the hierarchy of contingency that are qualified by the receptivity to change and are constantly in flux. ${ }^{42}$ Mullā Șadrā put forward at least nine arguments in favour of motion in the category of substance. ${ }^{43}$ Three should suffice to demonstrate the critique of Avicenna, since most of the arguments revert to these. The first and most important relates to how substance is the subject, ground and cause of change. All accidental change is predicated on the changing nature of the substance, since it is the substance that is consistently renewing: "The proximate cause for motion must be the ever-renewing existing thing of a fixed essence, and the proximate cause of every type of motion can only be nature that is a substance constituted by the body and occurrent by a species. [...] Therefore it is clear that every body must be an ever-renewing existence." ${ }^{44}$ The point about the ever-renewing nature of existence is tied to his notion of the constant 'renewal of creation' ( halq ğadid) that he draws from Ibn 'Arabī.

The second is that all accidental qualities pertain to the individuated substance that is the referent for the corporeal essence and its changing qualities: "The existence of every corporeal nature is essential to it such that the substance that is continuous, changing, temporal and locational is so by that essence. So quantities and colours and places must be changeable by the existence of the particular individuated corporeal substance and that is motion in substance." ${ }^{45} \mathrm{~A}$ parallel argument to this is based on the notion of time and its course.

The third relates to the nature of change and how the graduated nature of change as opposed to once and for all discrete changes requires the substrate of that change to be a stable essence of an existent substance in flux, and the ultimate substrate is prime matter. ${ }^{46}$ Once again he appeals to something beyond

42 Avicenna, The Physics of the Healing, ed. and tr. by Jon McGinnis (Provo, UT: Brigham Young University Press, 2009), book III, II, 26o-1; Mullā Șadrā, Asfār, v, 6-10.

'Abd al-Rasūl 'Ubūdīyat, Dar āmadī bih nizāam-i ḥikmat-i Șadrā̄ò (Qum: Mu’assasa-yi Imām Humaynī, 1391 Š/2012), I, 323-7. See Mullā Ṣadrā, Asfār, III, 61-2, 101-2, 104, 177-8, IV, 274, VII, 290-2, VIII, 11-2, and al-Šawāhid al-rubūbīya fi-l-manāhiğ al-sulūkīya, ed. by Sayyid Muștafā Muḥaqqiq Dāmād (Tehran: Bunyād-i hịikmat-i islāmī-yi Ṣadrā, 1382 Š/2003), 108.

46 Mullā Șadrā, Asfārr, IV, 459. 
analytic argument by saying that all those with sound mystical intuition recognise that motion must pertain to the substrate before it affects the accidents. ${ }^{47}$ The arguments on motion show that Mullā Șadrā has little utility for categoriology or for substance metaphysics as such. The link between his arguments for motion in substance and modulation in existence is clear: any change and differentiation in the structure of existence must be predicated on the simple fact that the essential nature of existence is in flux and differentiation but also a principle of unity. This goes flatly against the metaphysical pluralism of Avicenna and his Aristotelian substance metaphysics. Sadrian monism in a sense overwhelms all other considerations as these three challenges show. Insisting upon metaphysical pluralism motivates most of the Avicennian responses.

Mahdī Narāqī

2.1 Life

Muhạammad Mahdī b. Abī Darr Narāqī (d. 1209/1795) was arguably the most important philosopher of the eighteenth century and a prolific thinker who engaged critically with the work of Mullā Șadrā as well as continuing the Avicennan tradition through his commentaries especially on the Metaphysics of $a l$-Šifa ${ }^{3}{ }^{48}$ In particular one might say it was Mullā Șadrā's monism that irked him most. Born in Narāq around 1146/1732, he initially studied in Kāšān (where he later returned to teach), and then trained in Ișfahān with two thinkers with a reputation for philosophy. The fact that he studied with renowned teachers in Iṣfahān some twenty years after the Afghan occupation suggests the recovery of the city's intellectual milieu and the uninterrupted teaching, transmission and debate on philosophical arguments from the late Safavid period.

47 Mullā Șadrā, Asfār, IV, 457 .

48 A recent study is probably the best introduction to his philosophy: Reza Pourjavady, "Mullā Mahdī Narāqī," in Philosophy in Qajar Iran, ed. by Pourjavady, 36-65. For his biography, see Mīrzā Ḥasan Ḥusaynī Zunūzī (d. 1218/1803-4), Riyāọ al-ǧanna: min al-raw ḍa al-rābía, ed. by ‘Alī Rafīì (Qum: Kitābhāna-yi Āyatullāh Mar`ašī Nağafī, 1370 Š/1991), IV, 567-74; Mīrzā Muḥammad b. Sulaymān Tunikābunī (d. 1302/1885), Qiṣaṣ al-'ulamā̉, ed. by Muḥammad Riḍā Barzigār Ḩāliqī and 'Iffat Karbāsī (Tehran: Intišārāt-i 'ilmī u farhangī, 1389 Š/2010), 168-70; Sayyid Ḥasan al-Ṣadr (d. 1354/1935), Takmilat Amal al-āmil, ed. by Husayn 'Alī Mạ̣fūẓ, 'Alī al-Dabbāg̀ and 'Adnān al-Dabbāg̀ (Beirut: Dār al-aḍ̂ā', 1986), v, 492-6; Āqā Buzurg

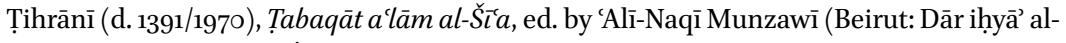
turāt, 2009), XII, 543-4; Ġulām-Husayn Hudrī, Ta’mmulì bar sayr-i taṭawwurī-yi ḥukamā va ḥikmat-i muta'āliya (Tehran: Mu’assasa-yi pažūhišī-yi ḥikmat u falsafa-yi Īrān, 1391 Š/2012), 319-3; Zādhūš, Dìdār bā fìlsūfān-i Sipāhān, 212-4. 
His teachers in philosophy were primarily two. The first was Muhammad Ismāîl b. al-Ḥusayn Māzandarānī Huwāğùu'i (d. 1173/176o), who is often invoked in a lineage that connected the philosophers of Isfahan in the Safavid period with an establishment of Șadrian philosophy in the Qāăār period, despite the fact that most of his works are very much of a juristic and theological nature. ${ }^{49}$ On the question of the creation of the cosmos he sided with Mīr Dāmād's notion of creation at the mediate level of perpetuity (hudūt dahrī, albeit on scripturalist grounds) and not Mullā Șadrā in his treatise on the Invalidity of Imaginary Time (Ibțāl al-zamān al-mawhüm). ${ }^{50}$ That text is a direct response to Ğamāl al-Dīn Huwānsārī's own defence of imaginary time and critique of Mīr Dāmād. ${ }^{51}$ As one manuscript (Ms Princeton New Series 749) suggests, it began life as a gloss on Hafrī's gloss on the 'new' Šarh al-Tağrìd. Even his Persian text on existence reflects a critical rejection of monism on scripturalist grounds (being incompatible with the true teachings of the Quran and the Imams), rejecting Mullā Șadrā's position on the ontological priority of existence (without naming him), and asserting that the unity of existence (wahdat al-wuğūd) cannot be philosophically reasoned. ${ }^{22}$ Most of Hwwāğùì's works are scripturalist and theological in nature, but in one case, a treatise entitled the Guidance of the Heart to Elements of the States of the Afterlife (Tamarat al-fu'àd ilā nabad min ahwāl al-ma'ād), he defended Mullā Ṣadrā's eschatology of the different bodies of the afterlife, created and re-created by the power of the human soul corresponding to those bodies, as an implicit critique of Avicennism. ${ }^{53} \mathrm{He}$ similarly responded to the standard critique of Mullā Sadrā that accused him of believing in metempsychosis (tanāsuh) by another method. ${ }^{54}$ He did demonstrate his knowledge of the Avicennian tradition, especially the commentary cycle on the Tağrìd al-itiqād of al-Ṭūsī, but he tied those discussions closely to hadīt to elucidate his points. Hwāğùu'i represented a certain tendency, influenced by Mullā Ṣadrā, that considered the teachings of certain

49 Sayyid Muḥammad Bāqir Mūsawī al-Hुwānsārī (d. 1313/1895), Raw ḍāt al-ğannāt fí aḥwāl al-'ulamā’ wa-l-sādāt (Beirut: al-Dār al-islāmiyya, 1991), I, 114-9; Mīrzā Muḥammad 'Alī Mudarris-i Tabrīzī (d. 1373/1954), Rayhānat al-adab fì tarāğim al-ma'rūfin (Tehran: Čāphāana-y Šafaq, 1954), II, 105-6; Āqā Buzurg Ṭihrānī, Țabaqāt a lāmm al-Šč́a, IX, 62-4; Hudrī, Ta’mmulì bar sayr-i tațawwuri-yi ḥukamā va hikmat-i mutáăliya, 274-81. Ismā'īl Huwāḡūùì, Ibțāl al-zamān al-mawhūm, in Ğalāl al-Dīn Davānī, Sab`rasā̉il, ed. by Sayyid Aḥmad Tūysirkānī (Tehran: Mīrāt-i maktūb, 1381 Š/2002), 241-83.

$5^{1}$ Ğalāl al-Dīn Davānī, Sab rasā̉il, 229-237.

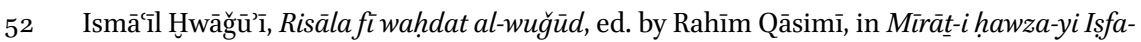
hān: daftar-i avval (Isfahan: Ustānlarī-yi Ișfahān, 1383 Š/2004), 138-41.

53 Huwāğū'ì, Țamarat al-fu'àd, in Muntahabātī, ed. by Āštiyānī, III, 229-306.

54 Huwāğù'î̀, Tamarat al-fu'ād, in Muntahabātī, ed. by Āštiyānī, III, 264-89. 
key hadit on ontological and cosmological matters to be entirely homologous with philosophical doctrines, usually of Neoplatonic provenance. Interestingly, Mullā Șadrā is nowhere mentioned in the text. ${ }^{55}$ Narāqī referred to Hwāğ $\bar{u} \overline{1}$ as 'our teacher the verifier' (ustā temporary source quoted him as having either studied or read or taught the Metaphysics of the $\breve{S}$ if $\tilde{a}$ ' at least thirty times and having memorised the entire text. ${ }^{57}$ Another contemporary source remembered him as foremost a philosopher (hakim) and theologian (mutakallim). ${ }^{58}$ Nevertheless, it is clear that as a philosopher, his student eclipsed him.

The second teacher was probably Muhammad Zamān Kās̄ānī (d. c. 1172/ 1759). ${ }^{59} \mathrm{He}$ had iğāzas from Sayyid Muhammad Ḥusayn Huātūnābādī (d. 1151/ 1739) dated 1147/1734, Mullā 'Abd al-Rahīm b. Ğafar (d. 1154/1741) the grandson of Muḥammad Bāqir Sabzawārī who had briefly served as Šayh al-Islām of Iṣfahān under Nādir Šāh (r. 1736-1747), and Mīrzā Muhạammad Bāqir b. 'Alā' alDīn Muḥammad Gulistāna (d. after 1120/1708). ${ }^{60}$ We do not know much about Kāšānī but some of his philosophical writings have survived. He wrote a gloss on Hwwānsārì's supergloss on Hुafrīs gloss on the Šarh al-Tağrīd of Qūšğī. Other works of his included treatises in law and a short critique of Sunni traditionalist hermeneutics known as the balkafa ('without asking how' on the modality of properties ascribed to God) entitled Guidance of the Righteous and Errors of Those Who Do not Ask How (Hidāyat al-mustaršidin wa-tahțiat al-mubalkafin) dated 1166/1753, which, on closer scrutiny, is probably more of a critique of Huāğưu'ì's scripturalist approach to theology. ${ }^{61}$ In his major work entitled Mir'āt al-zamān dated 1162/1749, he defended the position of the notion of 'imaginary' time (al-zamān al-mawhüm), an issue of debate in his time starting with Ğamāl Huwānsārī in the generation before him in his commentary on the Dawānī gloss

55 Huwāğù'î, Țamarat al-fu'ād, in Muntahabātī, ed. by Āštiyānī, III, 294-5.

$5^{6}$ Mahdī Narāqī, Ğāmi`al-afkār wa-nāqid al-anzāarr, ed. by Mağîd Hādī-zāda (Tehran: Intišārāt-i hịmat, 1381 Š/2002), I, 210.

57 Shaykh 'Abd al-Nabī al-Qazwīnī (d. c. 1197/1783), Tatmīm Amal al-āmil, ed. Sayyid Aḥmad al-Ḥusaynī al-Aškiwarī (Qum: Kitābḩāna-yi Âyatullāh Mar'ašī Nağafī, 1986), 67-8.

$5^{8}$ Zunūzī, Riyāẹ al-ğanna, II, 72-3.

59 Huwānsārī, Rawḍāt al-ğannāt, vII, 119-21; Hudrī, Ta’mmulì bar sayr-i tațawwurì-yi ḥukamā va ḥikmat-i muta āliya, 269-70; Zādhūš, Dìdār bā fìlsūfān-i Sipāhān, 189-9o.

6o Sayyid Mahdī Rağāàì, al-Iğāzāt li-ğam 'min al-'ulamā’ wa-l-fuqahā’ wa-l-muhaddițīn (Qum: Kitābhāna-yi Âyatullāh Mar'ašī Nağafî, 1386 Š/20o8), 19-28; al-Ḥusaynī, Talāmidatat al'Allāma al-Mağlisī, 93; Zādhūš, Dìdār bā fìlsūfān-i Sipāhān, 189; Āqā Buzurg TTihrānī, Țabaqāt a lām al-šč́a, IX, 94-5, 198-200, 426.

61 Muhammad Zamān Kāšānī, Hidāyat al-mustaršidīn wa-tahțiiat al-mubalkafinn, Ms Mağlis-i šūrā-yi islāmī Tehran 1966, fols. $17^{\mathrm{a}}-3^{\mathrm{b}}$, completed 1166/1752. 
on the Šarh al-tağrīd of Qūšğì, and then by his contemporary Ismācil Hwwāğù'̄ who criticised it in his Ibtāl al-zamān al-mawhūm. ${ }^{62}$

From these teachers, we can deduce that Narāqī had a decent grounding in Avicennian thought, tinged with influences from Mullā Șadrā, and a desire to connect that study with broadly theological and jurisprudential concerns, as was often the case in the early modern period in which philosophy was rarely compartmentalised from other disciplines in the Islamic East. As a polymath who wrote on a variety of issues and genres, Narāqī was described by his student as one who "unifies in himself the rational and the scriptural" (ğammic al-máqül wa-l-manqūl). ${ }^{63}$

Spending his final years teaching in Kāšān, Narāqī died on 8 Šacbān 1209/28 February 1795, according to the biography written by his son Ahmad in 1227/ 1812. His body was transported to Nağaf and buried near the shrine. There was no student with a significant standing to take on his legacy, despite the fact that his philosophical ideas and influences were the most interesting in the early Qāğār period (and demonstrated a deep knowledge of the thought of philosophers who came before). He achieved fame at a time when Kāšān was flourishing but Iṣfahān had recovered and the centre of culture and power was gravitating further north. Narāqi represented the culmination of an Avicennan tradition. While his commentary on al-Š $i f a$ ' was read, it seems a Sadrian reading of Avicenna prevailed. The success of his contemporary 'Alī Nūrī's establishment of Mullā Sadrā at the heart of the curriculum meant that at least for two generations Avicennism was eclipsed from the intellectual landscape of Iran until late in the Qāğār period; the only Gloss on the Metaphysics of al-Šif $\tilde{a}$, and that too a rather brief one on book 1, was written by Mïr Muhammad Husayn Huātūnābādī who explicitly sought to revive the reading of Huwānsārī albeit perhaps in vain. ${ }^{64}$ Certainly, that school of Avicenna seemed long gone by the time of Narāqì's death.

\subsection{Works}

Narāqī taught for many years in Kāšān and was a prolific writer including a series with the title 'Friend of' (Anis) that he wrote in Persian to make theology and $\breve{S}^{-}$ì law comprehensible to the merchant classes. At a time of the increasing

\footnotetext{
62 Muhammad Zamān Kāšānī, Mirāa al-zamān, ed. by Mahdī Dihbāšī (Tehran: Anğuman-i mafāhuir va ātār-i farhangī, 1384 Š/2005).

63 Muhammad Ğa'far Kabūdarāhangī "Mağdnūb 'Alī Šāh" (d. 1238/1823), Mir'āt al-ḥaqq, ed. Ḥāmid Nāḡī Iṣfahānī (Tehran: Intišārāt-i Mawlā, 1383 Š/2004), 70.

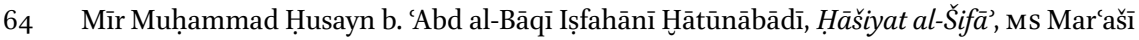
Qum 4838, autograph, foll. 1-2.
} 
dominance of the school of Mullā Șadrā, he remained an important Avicennian voice and followed the work and philosophical method of Țūsī, writing a number of studies in astronomy and mathematics including al-Mustaqșa $\bar{f} \mathfrak{\imath}$ 'ulüm al-hay'a, a large and comprehensive text on astronomy in Arabic in four chapters, Muhașșal masāil al-hay'a, six chapters on astronomy, Tahrïr (Persian explanatory translation) of Tuusìs version of the Sphaerics of Theodosius of Bithynia (d. c. 100 вСE), Tawdịh al-išk kāl, a Persian translation of Țūsì's work on Euclid (Tahrīr Uqlidūs), and some Glosses on the Almagest (al-Mağisțī) of Ptolemy.

In philosophy and theology, his major works included the following, starting with the commentaries on Avicenna and the Avicennian tradition. His commentary on the Metaphysics of al-šifa' of Avicenna covers the most glossed sections of the first two books (maquala) ending in chapter 4 of book 2. He demonstrated an excellent understanding of the Avicennian tradition through his critical use of the views of Bahmanyār, Nașī al-Dīn al-Ṭūsī, Faḩr al-Dīn al-Rāzī and Quṭb al-Dīn Taḥtānī Rāzī. ${ }^{65}$ He deployed Faḩr al-Dīn al-Rāzī as a representative of the Avicennian tradition-just as Mullā Ṣadrā did beforethrough his Eastern Discussions (al-Mabähịt al-mašriqūya); for example, when he wished to cite an Avicennian authority on the principle that once a thing becomes non-existent, it cannot return to its prior state (i'âdat al-ma'dūm). ${ }^{66}$ He also cited the Šìrāzī philosophers, Sayyid Șadr al-Dīn (often just named as al-Sayyid) and Giiyāt al-Dīn (Gíyāt al-ḥukamā’) Daštakī, as well as Šams al-Dīn Hafrī; in fact there is a strong sense in which he might be citing their views via al-Asfär of Mullā Șadrā. Often it seems that he adjudicates between the Huwānsārīs and Mullā Șadrā preferring the former at times, supporting the latter as well; this is at times done through a defence of the Šîrāzì philosophers against Huwānsārī (since Mullā Ṣadrā supported the positions of the Šìrāzīs) ${ }^{67}$

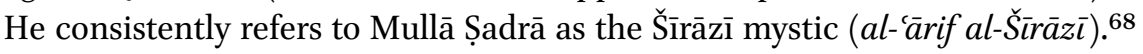
Further, he demonstrates his own independence from the Șadrian and Avicennian traditions, criticising al-Tūsì's position on explaining the empirical nature of causality, or Avicenna himself rejecting taqlid, or claiming at times that Mullā Șadrā failed to understand Avicenna. ${ }^{69}$

65 Mahdī Narāqī, Šarh al-ilāhīyāt min kitāb al-Šifä̀) ed. by Ḥāmid Nāăīi Ișfahānī (Qum: Hamāyiš-i Mullā Narāqī, 138o Š/2001), I, 363, 449, 457, 724, 25, 417, 523, 737, 332, 327, 764.

66 Narāqī, Šarh al-ilāhīyāt min kitāb al-Šifā', I, 459, citing Fahrr al-Dīn al-Rāzī, al-Mabāhị almašriqūya fì ilm al-ilāhīyāt wa-l-țabììyāt (Tehran: Maktabat al-Asadī, 1966), I, 47-8.

67 Narāqī, Šarḥ al-ilāhīyāt, I, 764-8.

68 Narāqī, Šarḥ al-ilāhīyāt, I, 147, 151, 165.

69 Mahdī Narāqī, Šarḥ al-ilāhīyāt, I, 63, II, 8og, I, 154, 194. 
His other major philosophical commentary was Compendium of Thoughts and Critique of Opinions (Ğämic al-afkar wa-nāqid al-anzār), completed in Kāšān in Rabī' I 1193/1779, on the proofs for the existence of God and Avicennian metaphysics. Although it appears to be an independent treatise that is incomplete, it is in effect a gloss on the commentary cycle of Tağrìd al-itiqa àd. In Qurrat al-'uyūn completed in 1182/1768, Narāqī said that he wrote Ğāmic on the commentary cycle on Avicenna's al-Išarat wa-l-tanbïhät. ${ }^{70}$ This suggests that the $\breve{G} \bar{a} m i i^{c}$ was probably commenced more than a decade before its completion date. Although the cycle of al-Išărāt is mentioned often (but not as frequently as the Metaphysics of $\left.a l-\check{S}_{i f} \vec{a}^{\prime}\right)$, he stated in the introduction that he would discuss the nature of God and his attributes following the commentaries on the 'New Commentary' (šarh ğadīd) on the Tağrìd al-itiqād by 'Alī al-Qū ǔğì. ${ }^{71}$ As we mentioned above, the third section (al-maqșad al-tālit ) of the Tağrìd on the proof for the existence of a creator (ițbāt al-șānic) was a much glossed text that reflected the Avicennian tradition; most of the Safavid and later glosses built upon the one by Hafrī who focused his analysis on the three attributes of power (which includes how God creates and the relation between God and the cosmos or the eternal and the mutable), knowledge, and speech, along with an Avicennian proof for divine simplicity. ${ }^{72}$ Nārāqi followed these emphases: his work is divided into three sections $(a b w \bar{a} b)$ - the first two on kataphatic affirmations of God's power and knowledge, and the third on apophatic denials of what God is not that follows the analysis of divine simplicity. These are prefaced by the long discussion on establishing the existence of God which examines some of the key assumptions in the Avicennian argument: the impossibility of an infinite regress, the nature of causality, the process of preponderance whereby a cause brings into existence something that was previously indifferent to existence and non-existence, and the different ways in which philosophers, theologians and Sufis demonstrate the existence of God. ${ }^{73}$ If one keeps in mind the typology of arguments that are mentioned by al-Ṭūsī in his Šarh al-išărāt, then the naturalistic argument from motion is missing. ${ }^{74}$

He wrote a few independent treatises. Cooling of the Eyes (Qurrat al-'uyūn), a treatise on existence and essence that attracted the critical attention of 'Alì

\footnotetext{
70 Mahdī Narāqī, Qurrat al-'uyūnfi-l-wuğūd wa-l-māhīya, ed. by Hasan al-'Ubaydī (Beirut: alMaḥağğa al-bayḍā', 2009), 54 .

71 Narāqī, Ğāmic al-afkār, I, 1.

72 Huafrī, Ta lìqa bar Ilāhìyàt, 99-155, 169-99, 207-19.

73 Narāqī, Ğâmical-afkār, I, 4-148; see also Firouzeh Saatchian, Gottes Wesen-Gottes Wirken: Ontologie und Kosmologie im Denken von Šams al-Dīn Muhammad al-Hafrī (gest. 942/1535) (Berlin: Franz Schwarz Verlag, 2011), 128-96.

Ibn Sīnā, al-Išărāt wa-l-tanbīhāt, III, 66-7.
} 
Nūrī and Shaykh Ahmmad al-Ahsā'ī, was completed in Rabī' II, 1182/1768 and in some ways acts as a companion work to Ğämi al-afkār. ${ }^{75}$ There are fourteen discussions ranging from the ontological priority of existence and the modulation of existence to how it is existence that is emanated from God, but it also contains an important critique of the views of Dawānī on existence (section twelve) and a refutation of the monist doctrine of the unity of existence (wahdat al-wuğüd) in section thirteen. ${ }^{76}$ It is precisely those last few chapters on the unity of existence that mark out the distinction of this treatise, and they constitute the longest section of the text. His critique actually drew on Mullā Șadrā's criticism of the position of Șadr al-Dīn Qūnawī (d. 673/1274) via that of 'Alā' al-Dawla al-Simnānī (d. 736/1336), and he provided seven ways of making sense or 'correcting' the concept of the unity of existence.

He also has a trilogy of texts in Arabic in descending complexity of argument and length of discussion that all begin with an ontological preliminary on the nature of existence and essence. The first is Flashes from the Divine Empyrean (al-Lama'ät al-aršrya a). ${ }^{77}$ In the introduction he announced five sections: on existence and essences (general ontology), on the attributes of God and divine agency, on the nature of his creation and the emanation of the cosmos, on the nature of the human soul and its activities, and on prophecy and resurrection. However, the text seems incomplete as it finishes with the discussion on Mīr Dāmād's notion of perpetual creation at the end of section three. The second section overlaps with elements of Ğämi' al-afkār and the first section is his most detailed exposition of his general ontology where the broad influence of Mullā Sadrā's tripartite doctrine of the ontological priority of existence, its modulation and its emanation is clear (așālat al-wuğüd, taškikkal-wuğūd and mağ ūlīyat al-wuğùd).

Then its epitome is Divine Flash on Transcendental Philosophy (al-Lum'a alilahìy fi-l-hikma al-mutacaliya) on the Șadrian tradition. ${ }^{78}$ It is divided into five sections $(b \bar{a} b)$ with each further divided into flashes (lum'a): existence and essence (including the Șadrian arguments for the ontological priority and modulation of existence and the chain of existence as the direct creation of God); proof for the existence of God (following the Avicennian model of the Nec-

75 The newer edition by al-'Ubaydī includes the glosses on Bīdābādī responding on the question of monism—see Narāqī, Qurrat al-'uyūn, 263-73.

76 Mahdī Narāqī, Qurrat al-'́uyūn, ed. by Sayyid Ǧalāl al-Dīn Āštiyānī (Tehran: Institute of Philosophy, 1978), 138-6o, 161-235.

77 Mahdī Narāqī, al-Lama'āt al-'aršìya, ed. by 'Alī Awğabī (Tehran: Intišārāt-i kitābhāna, mūza va markaz-i asnād-i Mağlis-i Šūrā-yi islāmī, 1381 Š/2002).

78 Mahdī Narāqī, al-Lum'a al-ilāhīya wa-l-kalimāt al-wağı̌za, ed. by Sayyid Ğalāl al-Dīn Āštiyānī (Tehran: Institute of Philosophy, 1978), 51-129. 
essary existence) and his properties, especially knowledge, power and speech; emanation and cosmogony including the Șadrian notion of nobler possibility (imkān ašraf), Platonic forms and the nature of the creation of the cosmos (hudūt al-álam); the nature of the soul and its lives, including a refutation of metempsychosis, and affirmation of the ontological status of the realm of similitudes ('âlam al-mițāl); and prophecy and his mission (but there is no discussion of the imamate).

Finally, the shortest version is its epitome Pithy Words (al-Kalimät al-wağ $z a),{ }^{79}$ which is divided into six sections: existence and properties of essence, including a discussion of the nature of creation, on individuation, on the analogy of existence and the different considerations (itibārāt) of essence; on the existence of God, his knowledge, agency and speech; on emanation and cosmogony, including the nature of the creation of the cosmos and how the argument of Mīr Dāmād is better than either the notion of imaginary time (alzamān al-mawhüm) or the Sadrian notion of motion in substance; ${ }^{80}$ on the nature of the soul and refutation of metempsychosis; on prophecy; and on the imamate and its rational incumbency based on the principle of divine facilitating grace (lutf).

\subsection{Thought}

Narāqī was a thoughtful critic of Mullā Șadrā, following him on some issues and not on others. For example, a question that was of debate in the Safavid period following the philosophers of Širāz was the consideration of the Godworld relationship through the existence-essence distinction that pertained to contingents in the Avicennian tradition. Narāqī sided with Mullā Șadrā on two related points here: when considering contingent beings which were conceptual composites of existence and essence, it was the former that was ontologically prior, the Sadrian doctrine known as the ontological priority of existence (așâlat al-wuğùd); concomitantly therefore, what is produced by God is existence and not essence (mağ ülìyat al-wuğüd). ${ }^{81}$ The ultimate referent for existence, on the basis of which we have a derivative concept of existence and which we then apply to contingents, is God insofar as he is a simple reality (haqīqa basița) devoid of an essence (muğarrad 'an al-māhīya). ${ }^{82}$ The mind then analyses the two aspects of each contingent as its existence (the deriva-

79 Narāqī, al-Lum'a al-ilāhīya, 133-55.

80 Narāqī, al-Lumia al-ilāhīya, 148.

81 Narāqī, Ğämi'al-afkār, I, 439; idem, al-Lama'āt al-'arščya, 19-22; idem, Qurrat al-'uyūn, 576 o.

82 Narāqī, al-Lama'āt al-'arš̌̀ya, 5 . 
tive concept of it) and its essence, holding them to be mentally and conceptually distinct. ${ }^{83} \mathrm{He}$ seems to hold that the conceptual distinction of essence and existence in the phenomenal world does not map onto reality; like Mulla Sadra, he does not think that essences exist in extramental reality. ${ }^{84}$ If it were essences that were ontologically prior, that would entail an infinite regress of non-existent things and nothing would exist. ${ }^{85}$ Essences insofar as they are universals do not exist in re and that by which something is what it is in its individuation is due to existence and not essence. ${ }^{86}$ Concomitantly, he holds that the different existents are related to one another through the semantics of modulation; existence is said of in many ways arranged in a modulated manner (mušakkaka) ${ }^{87} \mathrm{On}$ a related issue of ontology, he agrees with Mullā Ṣadrā’s presentation of nobler possibility which is the manner in which causality works in the hierarchy of existence whereby the nobler causes what is lesser, and the lesser desires the nobler; this is ultimately a proof for the intelligible realm and the hierarchical nature of emanation. ${ }^{88}$ Yet, he recognises, like others before him from the Avicennian tradition that Mullā Șadrā was not an 'orthodox' adherent of Avicennism, and he consistently refers to him as the Shirazi mystic (al-'árif al-ššr $\bar{a} z \bar{\imath}) .{ }^{89}$ One further point on which he differs with Avicenna and broadly agrees at one level with Mullā Sadrā is in his affirmation of the reality of Platonic forms drawing upon Suhrawardī as well as the Theology of Aristotle, thus in a sense defending what he considers to be 'orthodox' Aristotelianism against Avicenna. ${ }^{90}$

He upheld the Sadrian infallibilist position on epistemology, which is based on the identity thesis (ittihāa d al- 'āqilwa-l-ma'qūl) and 'knowledge by presence' ('ilm hudūurī). ${ }^{91}$ Consistent with Mulla Sadra and other thinkers of a broadly Platonist persuasion in the Safavid period, but contrary to Avicenna, he affirms the existence of an ontological realm known as the 'world of images' ('âlam al-mita āl).92

Nevertheless, he is critical of a number of Sadrian positions. First, while he adopted the notion of modulation in existence (taškik al-wuğudd), follow-

\footnotetext{
83 Narāqī, al-Lama'āt al-'arš̌̀̃ya, 8-9.

84 Narāqī, Qurrat al-'uyūn, 54-8.

85 Narāqī, al-Lamáāt al-'aršìya, 6.

86 Narāqīi, al-Lama'āt al-'aršìya, 9.

87 Narāqī, al-Lama'āt al-'aršǐya, 23.

88 Narāqīi, al-Lama'āt al-'aršìya, 403-13.

89 Narāqī, Qurrat al-'uyūn, 109, 121, 178, 190, 196, 197, 201.

90 Narāqī, al-Lama'āt al-'arščya, 446-55; Mullā Ṣadrā, Asfār, vI, 178-228.

91 Narāqī, Qurrat al-'uyūn, 76-8; Narāqī, al-Lama'āt al-'arščya, 12-4.

92 Narāqī, Qurrat al-'̌yūn, $111-5$.
} 
ing Ṭūsī, he considered it to be merely a logical concept and not something that pertains to actuality, nor is it something which is essential to the reality of existence, and in fact in doing so he might be reflecting a more 'orthodox' Avicennism stemming from Nașīr al-Dīn Ṭūsī. ${ }^{93} \mathrm{He}$ explicitly ruled out the possibility of a singular but modulated reality of existence, not least because of his opposition to ontological monism. ${ }^{94}$

Second, his most important disagreement lies in the issue of the hypostatic unity of existence. While accepting the possibility of a mystical intuition for the unity of existence (wahdat al-wuğüd), he does not think it can be rationally demonstrated or known. ${ }^{95} \mathrm{He}$ asserts that the Sufi contention that God is absolute existence (wuğùd muțlaq) and that existence is something singular, simple and undifferentiated (amr basiț šahșī) both violate our common sense observations (mušăhada), intellect ('aql) and intuition that, in actuality, there is a multiplicity of existents in reality. ${ }^{96}$ This is, as he says, despite the fact that "all great Sufis" agree that the intellect should decide such matters.

But it is not just the simple notion of the unity of existence that is undifferentiated and that seems to come from Qunawi that he criticises. He critiqued Mullā Șadrā's version of monism as well as Ibn 'Arabỉ's— that is the main thrust of his treatise the Cooling of the Eyes. He argues concomitantly that the issue of the simple reality being all things (basit al-haqiq a kullu l-ašy $\vec{a}^{3}$ ) is not established. ${ }^{97} \mathrm{He}$ did not approve of the extension of Avicenna's point about divine simplicity in a monist direction. It seems that his own sympathies lay with a metaphysical exposition that is a more Avicennian version of Mulla Sadrā. To critique the point, he posited the following argument. Consider the concept of Zayd and the concomitant concepts that we may have-that Zayd is a human, that he is a writer and that he is not a horse. All of these cannot be at the same level united as one, because the law of the excluded middle does not allow for Zayd to be some existence (a writer) and some non-existence (nothorse) at the same time..$^{98}$ With Avicenna, he affirms the actual plurality of contingent existents. ${ }^{99} \mathrm{He}$ cited previous critics of Mullā Șadrā on the issue of unity, drawing upon Hुwānsārī and Muḥammad Tunikābunī known as Fāżil-i

\footnotetext{
93 Narāqī, al-Lama'āt al-'aršìya, 22-5; idem, Qurrat al-'uyūn, 65-70; idem, al-Lum'a al-ilāhìya, 79; idem, Šarh al-ilāhīyāt, I, 426-9.

94 Narāqī, al-Lama'āt al-'aršrỹa, 30-1.

95 Narāqī, Qurrat al-'uyūn, 218-21; idem, Ǧāmi' al-afkār, I, 138-41.

96 Narāqī, Ǧāmic al-afkār, I, 139-41.

97 Narāqī, Qurrat al-'uyūn, 205.

98 Narāqī, Qurrat al-'uyūn, 202.

99 Narāqī, Qurrat al-'uyūn, 115-20.
} 
Sarāb (d. 1124/1713); he also cited Huwānsārī's contention that the Sadrian position reflects the dominance of poetic language over rational content. ${ }^{100}$ And in an implicit critique of the Sadrian equation of knowledge and existence, he contended that the fallacy of the unity of existence reverts to the conflation of ontology and epistemology. ${ }^{101}$

Narāqī suggested that Mullā Ṣadrā has been misled by Huafrī and quoted in detail the latter's position that only God exists and everything else is merely a mental conceptualisation that we have from the conceptualisation of God's existence; and that God is hidden and contingents are the manifest, but in actuality they are indistinct since the hidden and manifest are aspects of the same thing. ${ }^{102}$ Narāqi cannot accept such dissolution of the ontological distinction between the creator and the created. He summarises the position in the following manner:

The doctrine of the Sufis and explicit sayings of many recent scholars is that existence and the existent are one but that this singular existence is taken in different considerations whereby the levels of that existence are only considerations posited in the mind because reality across all levels is one. The mentally posited distinction is sometimes negatively conditioned (bi-šarț lā-šay $)$, sometimes unconditioned (lā bi-šarț $)$ and sometimes conditioned (bi-šart šay') due to the descent of existence from the highest level to the remainder. [...] Contingent existences are conceptualisations in the mind, manifestations and disclosures of the Real existence and rays of his light and shadows of his illumination. ${ }^{103}$

Part of the problem for Narāqī is Mullā Șadrā's claim that he knows this on the basis of a mystical intuition and not on the basis of rational proof; and the fact that he uses poetical language by describing contingents as mirrors of the divine. ${ }^{104}$ But more significantly, although Șadrā does not say so explicitly, in effect the Sufi position of unity makes the totality of existence into an essence that can be conditioned in three ways and seems to point towards the onto-

\footnotetext{
100 Narāqī, Qurrat al-'uyūn, 234-5.

101 Narāqī, Qurrat al-'uyūn, 217.

102 Narāqī, Qurrat al-'uyūn, 181-3; Hafrī, Sitt rasāil fi ițbāt wāğib al-wuğūd bi-l-d̄āt wa fi lilāhīyāt, ed. by Firūza Sā'atčīyān (Tehran: Intišārāt-i kitābhāna, mūza va markaz-i asnād-i Mağlis-i Šūā-yi islāmī, 139o Š/2011), 152-3.

103 Narāqī, Qurrat al-'uyūn, 185-7.

104 Narāqī, Qurrat al-'uyūn, 190.
} 
logical priority of essence (așâlat al-māhìya). Furthermore, it conflates two possible senses of 'absolute existence,' the former being a concept abstracted from one's observation of contingent essences and the other being the actual pure existence of the divine. ${ }^{105}$ This is one of the reasons why he rejected Mullā Sadrā's appropriation of the modalities of essence for an analysis of existence. Mullā Ṣadrā takes the three considerations of essence (lā bi-šarț, bi-šart lā šay', $b i$-šart šay') from the Metaphysics of al-šif $\tilde{a}^{\prime}$ and applies them to the three ways in which to consider existence while retaining its unity, and which he calls absolute (muțlaq), delimited (muqayyad) and deployed existence (munbasiț.). ${ }^{106}$ Narāqī summarised his objection:

As for these three levels of existence, I mean reality taken negatively conditioned, reality unconditioned and reality with a condition, either they must be distinct in actuality ( $\left.f i l-w \bar{a} q i^{i}\right)$ and the fact itself (nafs al-amr) or they must be distinct simply in the mind and in consideration. If it is the former, then unity of existence is not realised because the existence of the Necessary is one thing, and the existence of contingents another. And that third mode of existence-existence deployed (munbasit) is another thing again. But none of the Sufis claim this nor does the mystic [Mullā Sadrā] claim so as is clear in the passages presented. If it is the latter, as seems to be explicit in the writings of Sufis and resembles what is quoted above from the mystic [Mullā Șadrā], then there is no distinction between these levels in actuality but only in mental consideration, and thus one could apply Real existence to the first level or to the second or any, and how can one grasp one thing from these differences? 107

The problem is that Sufis_-and he cites Ibn 'Arabī as well as Mullā Șadrā's approval - sometimes use unconditioned reality of existence and sometimes negatively conditioned reality of existence to apply to God. This reverts to the old problem of the conflation of two senses of absolute existence mentioned.

Third, on the incipience of the soul, Narāqī rejects the Sadrian doctrine that the soul is corporeal in its incipience and argues for its spiritual incipience (rühaniyat al-ḥudüt) consistent with the Avicennian tradition. ${ }^{108}$ In fact, the

\footnotetext{
105 Narāqī, Qurrat al-'uyūn, 172.

106 Ibn Sīnā, al-Šifä̀: al-ilāhīyāt, I, 213-9; Mullā Șadrā, Asfār, II, 15-6, II, 330-2, 346-7.

107 Narāqī, Qurrat al-'uyūn, 175-8.

108 Narāqī, al-Lum'a al-ilāhìya, 96-101.
} 
radical distinction between body and the soul and the fact that the soul does not become corrupted or non-existent with the corruption of the body means that its origins and its final state are non-material and non-corporeal in reality. Part of the reason is that one thing cannot become another-and Narāqi rejected motion in substance. ${ }^{109}$

Furthermore, on the question of the incipience of the cosmos, he sets aside Mullā Șadrā's theory of motion in substance as a means for reconciling an eternal cosmos with God's creative agency, and opts instead, following his teacher Huwağ ù'ī, for Mīr Dāmād's notion of perpetual creation (ḥudūt dahrī). ${ }^{110}$ In the Flashes from the Divine Empyrean, he begins by setting out three positions: the philosophers hold that the cosmos is posterior to God in a purely logical sense insofar as it is preceded only by the very essence of God; the theologians hold that the cosmos is posterior to God in time and hence it is preceded by nonexistence in time; and the third is a recent position — and he means that of Mīr Dāmād - that the cosmos begins in perpetuity (dahr) so that it is properly preceded by non-existence and there is a separation (infika k) from the divine essence. ${ }^{111}$ He deals with various objections to the theory of Mīr Dāmad. Consider the following two. First, the divine essence insofar as it is a perfect cause is sufficient for the cosmos; positing any separation either by time or by perpetuity would violate the notion of the perfect cause. Second, God is the most perfect thing that can be conceived and therefore it would not be appropriate to consider when divine agency and causation began and when it ended. In both cases, positing a separation between God and the cosmos is considered to be a postulation of deficiency in God. Narāqi responds by saying that the separation defends the contingency of the cosmos since it is precisely that contingency which constitutes a relative deficiency. It is therefore not the perfection of God that is at stake but ensuring the contingency of the cosmos. ${ }^{112}$ Finally, in his summary of why this is the best way to understand the incipience of the cosmos, he appeals to the authority of the Theology of Aristotle: the foundations and pillars of the cosmos, such as the celestial spheres and the elements, do not exist in time (zamān), rather they exist in perpetuity $($ dahr $) .113$

\footnotetext{
109 Narāqī, Šarḥ al-ilāhīyāt, II, 730-754.

110 Narāqī, Ǧāmi' al-afkār, I, 178-243; idem, Šarḥ al-ilāhīyāt, 92-5.

111 Narāqī, al-Lama'āt al-'aršrìya, 468-9.

112 Narāqī, al-Lama'āt al-'aršrìya, 470-1.

113 Narāqīi, al-Lama'āt al-'arš́̌̀a, 484.
} 
Narāqī represented a developed and transformed Avicennism and provides further evidence for the dossier of how commentatorial traditions do not simply defend doctrines but developed them in dynamic ways. Narāqī saw Mullā Ṣadrā as a reasonable reader of Avicenna but he was critical of some key issues, not least of metaphysical monism, returning to the text of Avicenna and his earlier commentators. Significantly, he perpetuated the reading of Avicenna on creation that considered Mīr Dāmād's solution of creation at the level of perpetuity to be the most reasonable understanding of Avicenna's insistence on the contingency and necessity of the cosmos as well as the denial of the theological doctrine of creatio ex nihilo in time. Nevertheless, Narāqī represented in some ways the last moment of the significance of the Avicennian tradition as it was being replaced by Mullā Sadrā. In later generations, the critiques of Mullā Sadrā were broadly ignored by the mainstream of the seminarian study of philosophy and even in the philosophy departments of the Iranian universities. Similarly, when one looks at the works of contemporary Avicennians such as Yahyā Yatribī or those editing and writing on the Avicennian tradition such as Ḥasanzāda Āmulī, it is clear that they have been extensively influenced by the Sadrian tradition - and this was already clear in the work of Narāqī. The case study of the thought of Mahdī Narāqī shows how Avicennisms were constantly in the process of changing and shifting - and it demonstrates one of the key insights of the late Pierre Hadot about how the history of philosophy often develops through processes of creative misreadings of the forebears.

\section{Bibliography}

\section{Primary Sources}

'Alī-qulī b. Qarağḡāy Hुān. Ihyả̄-yi hikmat. Ed. by Fāṭima Fanā. 2 vols. Tehran: Mīrāt-i maktūb, 1377 Š/1998.

(Ps.-)Aristotle. Uțūlūğiyā. In Aflūțīn 'ind al-arab. Ed. by 'Abd al-Raḥmān al-Badawī. Cairo: L'Institut français, 1947.

Āštiyānī, Sayyid Ğalāl al-Dīn and Henry Corbin, eds. Muntahabātī az ātāarr-i hukamāà-yi ilāhī-yi İrān. 4 vols. Qum: Daftar-i tablīgāat-i islāmī, 1378 Š/1999.

Avicenna (Ibn Sīnā). al-Šif ẳ: ilāhìyāt. Ed. by Ğ. Anawātī, Saīì Zāyid, Ibrāhīm Madkūr et al. Cairo: al-Hay’a al-miṣrīya al-'āmma li-l-kitāb, 196o.

Avicenna (Ibn Sīnā). al-Šifẳ: fi-l-nafs. Ed. by Ğ. Anawātī, Saīì Zāyid, Ibrāhīm Madkūr et al. Cairo: al-Hay’a al-miṣrīya al-āmma li-l-kitāb, 196o. 
Avicenna (Ibn Sīnā). The Metaphysics of the Healing. Ed. and tr. by Michael Marmura. Provo, UT: Brigham Young University Press, 2005.

Avicenna (Ibn Sīnā). al-Išārāt wa-l-tanbīhāt ma šarḥay. Ed. by Maḥmūd Šihābī. 3 vols. Qum: Našr al-balāg̉a, 1375 Š/1996.

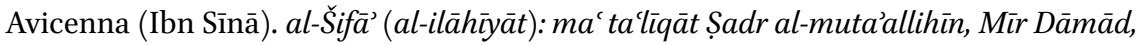
al-Alawī, al-Hwwānsārī, al-Sabzawārī, Mullā Sulaymān, Mullā Awliyā̄ wa-ġayrihim. Ed. by Ḥāmid Nāḡī Iṣfahānī. Tehran: Anğuman-i mafāhuir va ātār-i farhanḡ̄, 1383 Š/2004.

Avicenna (Ibn Sīnā). The Physics of the Healing. Ed. and tr. by Jon McGinnis. 2 vols. Provo, UT: Brigham Young University Press, 2009.

Bahmanyār. Kitāa al-tahṣ̂̄l. Ed. by Murtaḍā Muṭahharī. Tehran: Tehran University Press, 1375 Š/1996.

Daštakī, Mīr Ġiyāț al-Dīn Manșūr. Muṣannafāt. Ed. by 'Abd Allāh Nūrānī. 2 vols. Tehran: Anğuman-i mafāhirir va ātār-i farhangī, 1386 Š/2007.

Daštakī, Mīr Ġiyāț al-Dīn Manșūr. Šifẵ al-qulūb wa-tağawhar al-ağsām. Ed. by 'Alī Awğabī. Tehran: Intišārāt-i kitābhāna, mūza va markaz-i asnād-i Mağlis-i Šūrā-yi Islāmī, 139o Š/2011.

Fārābī. Šarḥ risālat Zīnūn. Ed. by Ḥāmid Nāği Iṣfahānī. In Ganǧina-yi Bahāristān Hikmat II. Ed. by 'Alī Awğabī. Tehran: Kitābhāna, mūza va markaz-i asnād-i Mağlis-i Šūrā-yi Islāmī, 1387 Š/20o8.

Kāšānī, Muhammad Zamān. Hidāyatal-mustaršidīn wa-tahțịatal-mubalkafìn. Ms Mağlis-i šūrā-yi islāmī Tehran 1966.

Kāšānī, Muhammad Zamān. Mir'āt al-zamānn. Ed. by Mahdī Dihbāšī. Tehran: Anğumani mafāhnir va ātār-i farhangī, 1384 Š/2005.

Hafrī, Šams al-Dīn Muḥammad. Hāāšya al-muhāākama bayn šarḥay al-išārāt. Ed. by 'Abd Allāh Nūrānī. In Ganğìna-yi Bahāristān: Hikmat I. Ed. by 'Alī Awğabī. Tehran: Intišārāt-i kitābhāna, mūza va markaz-i asnād-i Mağlis-i Šūrā-yi Islāmī, 1379 Š/20oo, 137-199.

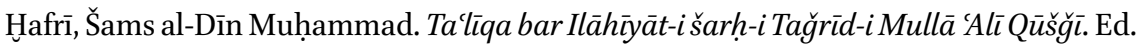
by Firūza Sāeatčīyān. Tehran: Mīrāt-i maktūb, 1382 Š/20o3.

Hafrī, Šams al-Dīn Muhammad. Sitt rasāil fí ițbāt wāăib al-wuğūd bi-l-dāat wa fi-l-ilāhìyāt. Ed. by Firūza Sā'atčīyān. Tehran: Intišārāt-i kitābhāna, mūza va markaz-i asnād-i Mağlis-i Šūrā-yi islāmī, 139o Š/2011.

Huātūnābādī, Mīr Muḥammad Ḥusayn b. 'Abd al-Bāqī Iṣfahānī. Hāǎšiyat al-Šifä̀. Ms Mar'ašì Qum 4838.

Huwāğū'ī, Ismāc̄il Māzandarānī. Ibṭāl al-zamān al-mawhūm. In Ğalāl al-Dīn Davānī. Sabc rasā’il. Ed. by Sayyid Aḥmad Tūysirkānī. Tehran: Mīrāt-i maktūb, 1381 Š/2002, 241-83.

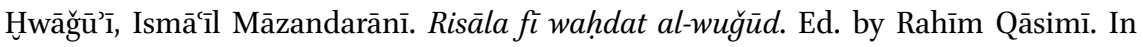
Mīrāt-i hawza-yi Ișfahān: daftar-i avval. Isfahan: Ustānlarī-yi Iṣfahān, ${ }_{3} 83$ Š/2004, $138-41$. 
Lāhīḡì, 'Abd al-Razzāq. Gawhar-i murād. Ed. by Zayn al-'Ābidīn Qurbānī Lāhīḡī. Tehran: Daftar-i tablīgāat-i islāmī, 1388 Š/20o9.

Lāhīḡī, 'Abd al-Razzāq. Šawāriq al-ilhām fı̌ šarh Tağrīd al-kalām. Ed. by Akbar Asad 'Alīzāda. 5 vols. Qum: Mu’assasa-yi Imām Ṣādiq, 1391 Š/2012.

Lāhīḡī, 'Abd al-Razzāq. al-Kalima al-țayyiba. Ed. by Ḥamīd 'Ațā̄ī Naẓarī. Tehran: Mu’assasa-yi pažūhišī-yi hiikmat va falsafa-yi İrān, 1391 Š/2012.

Narāqī, Mahdī b. Abī Darr. Qurrat al-'uyūn. Ed. by Sayyid Ǧalāl al-Dīn Āštiyānī. Tehran: Institute of Philosophy, 1978.

Narāqī, Mahdī b. Ab̄̄ Darr. al-Lum'a al-ilāhīya wa-l-kalimāt al-wağizaa. Ed. by Sayyid Ğalāl al-Dīn Āštiyānī. Tehran: Institute of Philosophy, 1978.

Narāqī, Mahdī b. Abī Darr. Šarh al-ilāhīyāt min kitāa al-Šifā̉. Ed. by Ḥāmid Nāḡīișfahānī. 2 vols. Qum: Hamāyiš-i Mullā Narāqī, 138o Š/2001.

Narāqī, Mahdī b. Abī Darr. al-Lama āt al-'arščya. Ed. by 'Alī Awğabī. Tehran: Intišārāt-i kitābhāna, mūza va markaz-i asnād-i Mağlis-i Šūrā-yi islāmī, 1381 Š/2002.

Narāqī, Mahdī b. Abī Darr. Ğāmi` al-afkār wa-nāqid al-anzạār. Ed. by Mağīi Hādī-zāda. 2 vols. Tehran: Intišārāt-i hiikmat, 1381 Š/2002.

Narāqī, Mahdī b. Abī Darr. Qurrat al-'uyūn fì-l-wuğūd wa-l-māhīya. Ed. by Hasan al'Ubaydī. Beirut: al-Maḥağğa al-bayḍā', 2009.

al-Rāzī, Fah̆r al-Dīn. al-Mabāhịt al-mašriqūya fì 'ilm al-ilāhīyāt wa-l-țabīìyāt. 2 vols. Tehran: Maktabat al-Asadī, 1966.

Šīrāzī, Mullā Șadrā. al-Šawāhid al-rubūbōya fì-l-manāhiğ al-sulūkīya. Ed. by Sayyid Muṣṭafā Muḥaqqiq Dāmād. Tehran: Bunyād-i ḥikmat-i islāmī-yi Ṣadrā, 1382 Š/20O3.

Šīrāzī, Mullā Ṣadrā. Šarh wa ta līqāt 'alā Ilāhīyāt al-Šifä’ Ed. by Nağaf-qulī Habībī. 2 vols. Tehran: Intišārāt-i Bunyād-i ḥikmat-i islāmī-yi Ṣadrā, 1382 Š/2003.

Šīāz̄ī, Mullā Ṣadrā. al-Hikma al-mutacāliya fì-l-asfār al-'aqlīya al-arba'a. Ed. by Sayyid Muhammad Ḩāminihī et al. 9 vols. Tehran: Intišārāt-i Bunyād-i hiikmat-i islāmī-yi Ṣadrā, 1383 Š/2004.

Tabrīzī, Rağab 'Alī. Ițbāt-i vāğib. In Muntahabātī az ātāarr-i ḥukamā’yi ilāhī-yi Īrān. Ed. by Sayyid Ğalāl al-Dīn Āštiyānī. Qum: Daftar-i tablīgàat-i islāmī, 1378 Š/1999, I, 23958.

Tabrīzī, Rağab 'Alī. Aṣl al-aṣill. Ed. by 'Azīz Ğavānpūr Hiravī and Ḥasan Akbar Bayraq. Tehran: Anğuman-i mafāhnir va ātāār-i farhangī, 1386 Š/2007.

al-Ṭihrānī Rāzī, Mīr Qawām al-Dīn. 'Ayn al-ḥikma wa-tálīqāt. Ed. by 'Alī Awğabī. Tehran: Intišārāt-i kitābhāna, mūza va markaz-i asnād-i Mağlis-i Šūrā-yi Islāmī, 1378 Š/1999.

\section{Secondary Sources}

Açikgenç, Alparslan. Being and Existence in Sadra and Heidegger: A Comparative Ontology. Kuala Lumpur: ISTAC, 1993.

Amin, Wahid. Nașir al-Dìn Ṭūsì and the Avicennan Tradition: Metaphysics and Mental Existence. D.Phil. dissertation, Oxford, 2016. 
d'Ancona, Cristina. "Ex uno non fit nisi unum Storia e preistoria della dottrina avicenniana della prima intelligenzia." In Per una storia del concetto di mente. Ed. by Eugenio Canone. Firenze: L.S. Oschki, 2007, 29-55.

Bdaiwi, Ahab. Shi'i Defenders of Avicenna: An Intellectual History of the Dashtakī Philosophers of Shiraz. Ph.D. dissertation, Exeter, 2014.

Corbin, Henry. La philosophie iranienne islamique aux XVIIe et XVIIIe siècles. Paris: Buchet Chastel, 1981.

Dīnānī, Ġulām-Ḥusayn Ibrāhīmī. Ğalāl al-Dīn Davānī: filsūf-i dạwq al-ta’alluh. Tehran: Intišārāt-i Hirmis, 1395 Š/2016.

Dirāyatī, Mușțafā, ed. Fihristvāra-yi dast-nivišt-hā-yi İrān [Dinā] 12 vols. Qum: Al-Hādī, 1389 Š/2010.

Eichner, Heidrun. The Post-Avicennian Philosophical Tradition and Islamic Orthodoxy. Philosophical and Theological Summae in Context. Habilitationsschrift, Halle-Wittenberg, 2009 .

Eichner, Heidrun. "Handbooks in the tradition of later Eastern Ash'arism." In The Oxford Handbook of Islamic Theology. Ed. by Sabine Schmidtke. Oxford: Oxford University Press, 2016, 494-514.

Fanāī Aškivarī, Muhammad. Máqūl-i țānī: taḥlīlīaz anwā'-yimafāhīm-ikullì darfalsafayi islāmī va ġarbī. Qum: Intišārāt-i mu’assasa-yi āmūzīš va pažhūhišš-yi Imām Humaynī, 1387 Š/20o8.

Gösken, Urs. Kritik derwestlichen Philosophie in Iran. Zum geistesgeschichtlichen Selbstverständnis von Muhammad Husayn Ṭabātabā’̀ und Murtażā Muțahharī. Munich: Walter de Gruyter, 2014.

al-Ḥurr al-'Āmilī, Muḥammad Ḥasan. Amal al-āmil fı́ 'ulamā’ Ğabal 'Āmil. Ed. by Sayyid Aḥmad al-Ḥusaynī al-Aškiwarī. 2 vols. Nağaf: al-Mațba'a al-Haydarīya, 1966.

al-Ḥusaynī, Sayyid Aḥmad. Talāmidatat al-'Allāma al-Mağlisīwa-l-muğāzūn minhu. Qum: Kitābhāna-yi Āyatullāh Mar`ašī Nağafī, 1410/1989.

Jambet, Christian. Qu'est-ce que la philosophie islamique? Paris: Gallimard, 2011.

Kabūdarāhangī 'Mağdūb 'Alī Šāh', Muhammad Ğa'far. Mir'āt al-ḥaqq. Ed. by Ḥāmid Nāḡī Iṣfahānī. Tehran: Intišārāt-i Mawlā, 1383 Š/2004.

al-Hูwānsārī, Sayyid Muḥammad Bāqir Mūsawī. Raw ḍāt al-ğannāt fí aḥwāl al-'ulamā̄ wa-l-sādāt. 9 vols. Beirut: al-Dār al-islāmìya, 1991.

Hudrī, Gulām-Ḥusayn. Ta’ammul̄̄ bar sayr-i tațawwurī-yi ḥukamā va ḥikmat-i mutacâliya. Tehran: Mu’assasa-yi pažūhišī-yi hịmat u falsafa-yi Īrān, 1391 ک̌/2012.

McGinnis, Jon. "Nașīr al-Dīn al-Ṭūīi (d. 1274) Sharḥ al-ishārāt." in The Oxford Handbook of Islamic Philosophy. Ed. by el-Rouayheb and Schmidtke. 326-47.

Michot, Jean R. "La pandémie avicennienne au Vie/Xıı siècle." Arabica, 10.3 (1993): 287-344.

Mudarris-i Tabrīzī, Mīrzā Muhammad 'Alī. Rayhānat al-adab fì tarāăğim al-ma'rūfín. 7 vols. Tehran: Čāphāna-y Šafaq, 1954. 
Muțahharī, Murtażā. Šarh-i mabsūṭ-i manzūma. 4 vols. Tehran: Intišārāt-i Hiikmat, ${ }_{1363}$ Š/1985.

Muțahharī, Murtażā. Ușūl-ifalsafa va-raviš-i riālizm. 5 vols. Qum: Intišārāt-i Ṣadrā, 1382 $\check{S} / 2003$.

Nasr, Seyyed Hossein and Mehdi Aminrazavi, eds. An Anthology of Philosophy in Persia, Vol. 5: From the School of Shiraz to the Twentieth Century. London: Tauris, 2015.

Panzeca, Ivana. "On the Persian translations of Avicenna's Ilähiyyāt." Documenti e studi sulla tradizione filosofica medievale 28 (2017): 553-567.

Pourjavady, Reza and Sabine Schmidtke. "An Eastern renaissance? Greek philosophy under the Safavids." Intellectual History of the Islamicate World 3 (2015): 248-9o.

Pourjavady, Reza, ed. Philosophy in Qajar Iran. Leiden: Brill, 2018.

Puig, Josep. "Un tratado de Zenón el Mayor. Un comentaria atribuido a al-Farabi." $L a$ Ciudad de Dios 201 (1988): 287-321.

al-Qazwīnī, 'Abd al-Nabī. Tatmīm Amal al-āmil. Ed. by Sayyid Aḥmad al-Ḥusaynī alAškiwarī. Qum: Kitābhāna-yi Āyatullāh Mar'ašī Nağafī, 1986.

al-Rahim, Ahmed. The Creation of Philosophical Tradition: Biography and the Reception of Avicenna's Philosophy from the Eleventh to the Fourteenth Century AD. Wiesbaden: Otto Harrassowitz, 2018.

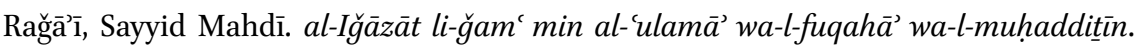
Qum: Kitābhāna-yi Āyatullāh Mar'ašī Nağafī, 1386 Š/20o8.

Rizvi, Sajjad H. Mullā Ṣadrā and Metaphysics: Modulation of Being. London: Routledge, 2009.

Rizvi, Sajjad H. "Hikma muta'āliya in Qajar Iran: Locating the Work of Mulla Hadi Sabzawari." Iranian Studies, 44.4 (2011): 473-96.

Rizvi, Sajjad H. "Alī Nūrī." In Philosophy in Qajar Iran. Ed. by Pourjavady. 125-78.

el-Rouayheb, Khaled and Sabine Schmidtke, eds. The Oxford Handbook of Islamic Philosophy. New York: Oxford University Press, 2017.

el-Rouayheb, Khaled. Islamic Intellectual History in the Seventeenth Century: Scholarly Currents in the Ottoman Empire and the Maghreb. Cambridge: Cambridge University Press, 2015.

Rudolph, Ulrich et al., eds. Philosophy in the Islamic World, Vol. 1 8th-1oth Centuries. Leiden: Brill, 2016.

Saatchian, Firouzeh. Gottes Wesen-Gottes Wirken: Ontologie und Kosmologie im Denken von Šams al-Dīn Muḥammad al-Hafrī (gest. 942/1535). Berlin: Franz Schwarz Verlag, 2011.

al-Ṣadr, Sayyid Ḥasan. Takmilat Amal al-āmil. Ed. by Ḥusayn 'Alī Maḥfūẓ, 'Alī al-Dabbāg̣ and 'Adnān al-Dabbāg. 5 vols. Beirut: Dār al-aḍwā', 1986.

Seidel, Roman. Kant in Teheran: Anfänge, Ansätze und Kontexte der Kantrezeption in Iran. Berlin: Walter de Gruyter, 2014.

Shihadeh, Ayman. "Al-Rāzī's (d. 1210) commentary on Avicenna's Pointers." In The 
Oxford Handbook of Islamic Philosophy. Ed. by el-Rouayheb and Schmidtke. 296325.

Ṭihrānī, Āqā Buzurg. al-Ḍarīa ilā taṣānīf al-Šča 29 vols. Beirut: Dār al-aḍwā', 1983.

Ṭihrānī, Āqā Buzurg. Ṭabaqāt a lām al-Šča. Ed. by 'Alī-Naqī Munzawī. 14 vols. Beirut: Dār iḥ̂ā' al-turāt, 2009.

Tunikābunī, Mīrzā Muḥammad b. Sulaymān. Qiṣaș al-'ulamā̉. Ed. by Muhammad Riḍā Barzigār Hูāliqī and 'Iffat Karbāsī. Tehran: Intišārāt-i 'ilmī u farhangī, 1389 Š/2010.

'Ubūdīyat, 'Abd al-Rasūl. Dar-āmadī bih nizām-i hikmat-i Ṣadrā'̄. 3 vols. Qum: Mu’assasa-yi Imām Humaynī, 1391 Š/2O12.

Wisnovsky, Robert. "One aspect of the Avicennian turn in Sunnī theology." Arabic Sciences and Philosophy 14 (2004): 65-100.

Wisnovsky, Robert. “Avicenna's Islamic reception.” In Interpreting Avicenna. Ed. by Peter Adamson. Cambridge: Cambridge University Press, 2013, 190-213.

Wisnovsky, Robert. "Avicennism and early exegetical practice in the commentaries on the Ishärāt." Oriens 41 (2013): 349-78.

Zādhūš, Muhammad Riżā. Dìdār bā fìlsūfān-i Sipāhān. Tehran: Mu’assasa-yi pažūhišì-yi hikmat u falsafa-yi Īrān, 1391 Š/2012.

Zakāvatī Qarāguuzlū, 'Alī-Riżāa "Sayrī dar naqd-i afkār-i Mullā Șadrā dar čahār qarn-i ahīr." Āyina-yi pažūhiš 10.57 (1378 Š/1999): 14-21.

Zunūzī, Mīrzā Ḥasan Husaynī. Riyạ̣̄ al-ğanna: min al-raw ḍa al-rābica. Ed. by 'Alī Rafīī. 5 vols. Qum: Kitābhāna-yi Āyatullāh Mar`ašī Nağafī, 137o Š/1991. 